\title{
Comments
}

\section{Affirmative Action After City of Richmond v. J.A. Croson Co.: A Response to the Scholars' Statement}

\section{Charles Fried $\dagger$}

Last spring thirty constitutional scholars and law school deans issued a statement in the wake of the Supreme Court's decision in Gity of Richmond v. J.A. Croson Co. The statement, which was reprinted in the June 1989 issue of The Yale Law Journal, encouraged state and local governments to continue with full vigor their support for affirmative action programs.

Appearing originally as a cri de ceur and moral exhortation on the part of those disappointed by the Court's decision in City of Richmond v. J.A. Croson Co., ${ }^{1}$ the constitutional scholars' statement was an entirely familiar example of attempted "spin control" and as such required no response. Offered recently in the pages of a journal of legal scholarship, ${ }^{2}$ it draws the comment that as a statement of the law it is strangely at odds with itself and at times quite misleading. It is strange as it adopts the tone at once of Chicken Little and Dr. Pangloss: Something terrible has hap-

† Carter Professor of General Jurisprudence, Harvard Law School. The writer was Acting Solicitor General and Solicitor General of the United States from June 1, 1985 until January 20, 1989. During this time the Solicitor General's Office filed briefs in a number of the cases discussed in this Response, including Wygant v. Jackson Board of Education, 476 U.S. 267 (1986); Watson v. Fort Worth Bank \& Trust, 108 S. Ct. 2777 (1988); City of Richmond v. J.A. Croson Co., 109 S. Ct. 706 (1989); and Wards Cove Packing Co. v. Atonio, 109 S. Ct. 2115 (1989).

1. 109 S. Ct. 706 (1989).

2. Constitutional Scholars' Statement on Affirmative Action After City of Richmond v. J.A. Croson Co., 98 Yale L.J. 1711 (1989) [hereinafter Statement]. 
pened, but it's not so bad after all. It is misleading insofar as it suggests that no proposition of significance was enunciated, and that those propositions that were enunciated somehow embrace, rather than severely limit, the availability of racial quotas and preferences.

Croson is significant. For the first time a majority ${ }^{3}$ of the Court holds unequivocally that all racial classifications-what the scholars' statement calls "inclusive"4 remedial measures as well as what it calls "invidious discrimination" or "exclusionary practices"-must pass strict scrutiny and be justified by a compelling governmental purpose. ${ }^{5}$ The scholars write that "[i]t would defy not only the Supreme Court's decisions but the fundamental purposes of the equal protection clause to conclude that the Constitution ... requires that such measures [presumably 'inclusive' ones] be treated in exactly the same way as the invidious discrimination of the nation's past." to slip past the clear statement in Croson-nothing in the law is exactly the same as anything else-but this device should satisfy no one. This is what Justice O'Connor writes: "We thus reaffirm the view expressed by the plurality in Wygant that the standard of review under the Equal Protection Clause is not dependent on the race of those burdened or benefited by a particular classification." O'Connor then specifically rejects the thesis of Justice Marshall's dissent that "[r]ace-conscious classifications designed to further remedial goals . . . are forthwith subject to a relaxed standard of review." Although the scholars' statement avoids using the terms of Justice Marshall's dissent and in a subordinate clause acknowledges that strict scrutiny applies, what Justice Marshall argues is the gist of what they argue, too. How else are we to give other than rhetorical force to the words I quote above, as well as to proposition "One" of Section II of the scholars' statement, which notes:

While the Supreme Court has stated that all governmental uses of race are subject to strict scrutiny, nearly all members of the Supreme Court have recognized that there is a critical moral and constitutional difference between governmental interests in employing race to

3. The disposition of the Justices is not so confusing as it seems at first sight. It is sufficient to note that Chief Justice Rehnquist and Justice White agree with Justice O'Connor on all points. Justice Kennedy suggests that he would be even tougher on racial preferences than Justice O'Connor, but he does not insist. And Justice Scalia disapproves of any race-conscious remedies, arguing that relief only to the actual victims of the governmental unit's own discrimination is not race-conscicus, but merely reverses the illicit race-conscious offense of the initial discrimination. You can't get much stricter than that.

4. Statement, supra note 2 , at 1712 .

5. The most extensive-and very hostile-analysis of Croson so far, Rosenfeld, Decoding Richmond: Affirmative Action and the Elusive Meaning of Constitutional Equality, 87 MICH. L. REv. 1729 (1989), states that "a majority on the Court for the first time has settled on a single standard-the strict scrutiny test," $i d$. at 1731 , and concludes that the case is a "turning point," $i d$.

6. Statement, supra note 2 , at 1712.

7. Croson, 109 S. Ct. at 721.

8. Id. 
correct historic discrimination-or even to promote diversity-and governmental interests in using race to advance debilitating stereotypes and the perpetuation of racial exclusion. ${ }^{9}$

Proposition "Two" is seriously misleading. The Supreme Court here has not, as the scholars say, merely "concluded that societal discrimination by itself cannot justify most race-conscious programs,"10 thereby implying that societal discrimination plus a smidgeon of something more would provide such a justification. Rather, Justice O'Connor, writing for the Court, explicitly picks up on a theme struck by Justice Powell in Regents of the University of California v. Bakke $e^{11}$ and Wygant v. Jackson Board of Education" that societal discrimination is an "amorphous" and "inadequate" basis for race-conscious measures. ${ }^{13}$ No theme was more important to Justice Powell's jurisprudence on this matter; it is exactly that theme which is embraced here; it is exactly the contrary of this theme that resonates throughout the dissents and the scholars' statement.

Even more troubling is the passage in that same section of the scholars' statement that notes: "[T]he Court has . . . rejected the notion that local governments may implement such remedial [race-conscious, preferential] programs only if they bear the tortuous and often divisive burden of documenting specific incidents of purposeful past discrimination on identified occasions."14 "[R]elevant statistical comparisons"15 are enough, and local governments should not be "forc[ed] . . . to point fingers needlessly." "16 But let us once again turn to the opinion in Croson. After rejecting the City's purported justification based on "past discrimination in an entire industry,"17 "the sorry history of both private and public discrimination in this country,"18 and statistical disparities of various sorts, Justice O'Connor concludes (this time explicitly for the Court): “There is nothing approaching a prima facie case of a constitutional or statutory violation by anyone in the Richmond construction industry." "Nothing we say today precludes a state or local entity from taking action to rectify the effects of identified discrimination within its jurisdiction."20 Thus, identified discrimination there must be and to that extent "fingerpointing," that is,

9. Statement, supra note 2, at 1712-13.

10. Id. at 1713 (emphasis supplied).

11. 438 U.S. 265 (1978).

12. 476 U.S. 267 (1986).

13. Croson, 109 S. Ct. at 723.

14. Statement, supra note 2 , at 1713.

15. Id.

16. Id. at 1714 .

17. Croson, 109 S. Ct. at 723 .

18. Id. at 724 .

19. Id. (emphasis in original).

20. Id. at 729 (emphasis supplied). 
identification. ${ }^{21}$ In this regard, it is worth recalling Justice O'Connor's statement in Watson v. Fort Worth Bank \& Trust:

[T]he plaintiff's burden in establishing a prima facie case goes beyond the need to show that there are statistical disparities in the employer's work force. The plaintiff must begin by identifying the specific employment practice that is challenged . . . [T] is in our view responsible for isolating and identifying the specific employment practices that are allegedly responsible for any observed statistical disparities. ${ }^{22}$

In Wards Cove Packing Co. v. Atonio, this statement was explicitly adopted by the Court as correct. ${ }^{23}$ Although Watson and Atonio were suits brought by minority plaintiffs charging violations of title VII of the Givil Rights Act of $1964,{ }^{24}$ it is hard to believe that the constitutional requirement of identification is more permissive. ${ }^{25}$ How far one must go in showing that the identified discrimination was also "purposeful" and what "purposefulness" means in this context are genuinely difficult and controverted issues. I do suggest, however, that the Court's recent jurisprudence makes it risky, to say the least, for local authorities to rely on the scholars' confident reassurance that the conditions for justifying racial preferences in this regard are not now quite rigorous. ${ }^{26}$

The scholars' Point "Four" states that "[i]n some social and economic contexts, race-conscious affirmative action is justified not only as a means of rectifying past discrimination, but also as a forward-looking way of promoting racial harmony."27 One cannot be sure, but I suppose this is a reference to Justice Powell's dictum in Bakke about the permissibility of seeking diversity in certain educational settings ${ }^{28}$ though never by fixed

21. The Court acknowledged that different criteria may be appropriate in evaluating the determinations of Congress acting under $\S 5$ of the Fourteenth Amendment. Croson, $109 \mathrm{~S}$. Ct. at 726-27. Croson was addressed to all other governmental actions at every level.

22. 108 S. C.t. 2777,2788 (1988).

23. 109 S. Ct. 2115,2124 (1989).

24. 42 U.S.C. $\$ \$ 2000 \mathrm{e}-2000 \mathrm{e}-17$ (1982).

25. See my discussion of Johnson v. Transportation Agency, 480 U.S. 616 (1987), and United Steelworkers v. Weber, 443 U.S. 193 (1979), infra note 47 and accompanying text.

26. The scholars' statement was issued in March, 1989, before the Court's decision in Wards Cove Packing Co. v. Atonio, 109 S. Ct. 2115 (June 5, 1989). That case made quite clear that at least under Titie VII, a mere statistical disparity will not cast upon the defendant the burden of proving that its practices were justified as reasonable. In any event, the plaintiff must identify the objectionable practices and prove a causal connection between those practices and the alleged exclusionary impact. Scholars cannot be faulted for not having crystal balls. Yet just last Term in Watson v. Fort Worth Bank \& Trust, 108 S. Ct. 2777 (1988), Justice O'Connor wrote to the same effect, though for only four members of an eight-person Court. Justice Kennedy was not yet able to participate in the Court's decision. But I would have supposed that had the scholars been advising a client rather than exhorting potential defendants to acts of courage, they would in prudence have concluded from Justice Kennedy's vote and opinion in Croson that he would make a fifth for the Watson plurality, which he did ultimately in Atonio.

27. Statement, supra note 2 , at 1713.

28. For recent considerations of this suggestion in light of Croson, see the array of opinions in 
quotas. Such speculation is enlightened, however, by what Justice O'Connor actually says for the Court on this point: "Classifications based on race carry a danger of stigmatic harm. Unless they are strictly reserved for remedial settings, they may in fact promote notions of racial inferiority and lead to a politics of racial hostility." ${ }^{29}$ Again citing Bakke, Justice O'Connor continues: "The desire to have more black medical students or doctors, standing alone, was not merely insufficiently compelling to justify a racial classification, it was 'discrimination for its own sake,' forbidden by the Constitution." ${ }^{30}$ And here is what Justice Stevens, concurring in the result, said on this score, "I . . . do not agree with the premise that seems to underlie today's decision, as well as the decision in Wygant $v$. Jackson Board of Education, that a governmental decision that rests on a racial classification is never permissible except as a remedy for a past wrong." 31

And of course the scholars' statement does not even advert-except by such equivocal and unelaborated qualifiers as "carefully designed,"32 "properly constructed,"33 and "carefully devised"34_to Section IV of Justice O'Connor's opinion (again explicitly for the Court), that even had the Richmond plan been "linked to identified discrimination," pass muster unless it was also "narrowly tailored" to the identified discrimination it was seeking to remedy. Beyond the fit to identified wrongs, narrow tailoring requires consideration "of race-neutral means to increase minority . . . participation." ${ }^{36}$ And among the bits of advice and encouragement that the scholars offer to local governments, there is no mention that one reason Richmond's plan was rejected by the Court was that "[t]here is no evidence in this record that . . . [the city] has considered any alternatives to a race-based quota." 37

Finally, in their eagerness to explain Croson away, the scholars jumble together the very different considerations appropriate to employment discrimination and minority business enterprise (MBE) set asides. Statistics in respect to entry-level employment opportunities are highly probative, because the notion of the relevant pool has a meaning that can be fixed without reaching for vague and all-encompassing explanations about why in many communities there may be few minority entrepreneurs to be dis-

Shurberg Broadcasting of Hartford v. FCC, 876 F.2d 902 (D.C. Cir. 1989); and in Winter Park Communications v. FCC, 873 F.2d 347 (D.C. Cir. 1989).

29. Croson, 109 S. Ct. at 721 (citing Regents of the Univ. of Cal. v. Bakke, 438 U.S. 265, 298 (1978)).

30. Id. at 722 (quoting Bakke, 438 U.S. at 307).

31. Id. at 730 (citation omitted).

32. Statement, supra note 2 , at 1712 .

33. Id.

34. Id.

35. Id. at 728 .

36. Id.

37. Id. 
criminated against. Such explanations inevitably lead to general considerations of poverty, differential educational opportunities, and the like-in short, societal discrimination. Justice O'Connor, for the Court, could not have been clearer about the importance of anchoring statistics in something more definite than just a general advertence to population figures. ${ }^{38}$ And, reaching beyond the Croson opinion, it is worth noting that unlike employment preferences, MBE's do not necessarily put any black employees to work. The status of a firm as a minority-owned business does not necessarily determine the composition of its work force. ${ }^{39}$ And this is why MBE programs have peculiarly lent themselves to manipulation and outright corruption. They are not about jobs; they are about money. ${ }^{40}$ They can be the pure instance of what Justice Powell decried as racial "bloc grants" in his Wygant opinion."

Croson is not a disaster to be deplored and explained away. It is a firm and noble affirmation that in this area, too, the end does not justify the means; that every time the government compels the use of race in the distribution of burdens and benefits a deep value of our constitutional polity is affronted. It is just this principle that the scholars deny by their invocation of the distinction between "inclusive" and "exclusionary" measures, and by their celebration of "forward-looking" justifications for racial preferences. ${ }^{42}$ Thus the scholars embrace an important and respectable principle. It is, however, not the one embraced by a majority of the Court. The scholars perhaps believe that because theirs is a moral as well as a legal principle, the Court's decision should be read narrowly so as to conflict as little as possible with it. They miss the point, however, that the Court's, too, is a moral principle, and as such has at least as much claim to be read generously or at least faithfully. ${ }^{43}$

Croson is also a welcome clarification and coming together by this Court under its new leadership of some themes that have been troubling the Court for more than a decade. The Court makes clear that a governmental unit may act to remedy not only its own past discrimination but that of identified others within its jurisdiction. ${ }^{44}$ But of greatest impor-

38. Id. at 723-26.

39. See, e.g., the definition of a qualifying MBE in the Richmond Ordinance, Croson, $109 \mathrm{~S}$. Ct. at 713 .

40. It is a further anomaly that enterprises that are truly integrated in terms of ownership or work force may not qualify as MBE's.

41. Wygant v. Jackson Bd. of Educ., 476 U.S. 267, 281 n.8.

42. The latter point has nowhere been more appealingly stated than by Kathleen Sullivan in Sins of Discrimination: Last Term's Affirmative Action Cases, 100 HaRv. L. Rev. 78 (1986). See also R. DWorkin, TAking Rights Seriously 223-39 (1978).

43. See R. Dworkin, supra note 42 , at 106-07.

44. The brief amicus curiae I signed as Solicitor General in Croson specifically urges this point and took issue with the Fourth Circuit in this regard. Brief for the United States at 6, 13-14, City of Richmond v. J.A. Groson Co., 109 S. Ct. 706 (1989) (No. 87-998). The only reason Wygant may have seemed to hold the contrary is that in the context of public education, no other relevant actors were on the scene. 
tance is the unequivocal affirmation that the equal protection clause protects all equally, and that all invocations of governmental power in racial terms, even those designated as benign, must overcome the highest burdens of scrutiny. The principal, perhaps the only, state interest ${ }^{45}$ sufficiently compelling to meet this burden is the remedying of identified acts of discrimination, though those who benefit from the remedy need not be the actual victims of that discrimination. Even then, race-conscious remedies must be narrowly tailored: They must fit the actual wrong remedied and ordinarily they must be used only as a last resort. ${ }^{46}$ In this respect Justice Scalia's concurrence is instructive. A remedy that goes to the actual victim is not race-conscious at all, it is victim-conscious. It is the nonvictim-specific and therefore race-conscious remedy that must not be reached for too readily, as many have been inclined to do and as I think the dissents and the scholars' statement encourages them to do.

Finally, Croson does not speak to affirmative action in the private sector. There, absent legislation, even invidious discrimination (though morally wrong and socially destructive) would not violate the law-which is why we needed the various Civil Rights Acts. The result may well be that Yale (so long as it acts voluntarily and not under any kind of governmental compulsion) $)^{47}$ but not Berkeley may engage in some quite freewheeling affirmative action. ${ }^{48}$ But then Yale but not Berkeley may open its classes with a prayer.

\footnotetext{
45. See Croson, 109 S. Ct. at 721 .

46.

Although we conclude that $\S 706(\mathrm{~g})$ [of Title VII of the Civil Rights Act of 1964] does not foreclose a district court from instituting some sorts of racial preferences where necessary to remedy past discrimination, we do not mean to suggest that such relief is always proper. . . . $[R]$ ace-conscious affirmative measures [should] not be invoked simply to create a racially balanced work force. In the majority of Title VII cases, the court will not have to impose [such remedies], but need only order the employer or union to cease engaging in discriminatory practices and award make-whole relief to the individuals victimized by those practices.
}

Local 28 of the Sheet Metal Workers' Int'l Ass'n v. EEOC, 478 U.S. 421, 475-76 (1986) (Brennan, $\mathrm{J}$.). In order to make a Court for this conclusion one must rely on Justice Powell's separate opinion, which states that "[i]n cases involving particularly egregious conduct a district court may fairly conclude that an injunction alone is insufficient to remedy a proven violation of Title VII." Id. at 483-84. Justice Kennedy, who takes Justice Powell's seat, may hardly be expected to be less rigorous on this score.

47. Wards Cove Packing Co. v. Atonio, 109 S. Ct. 2115 (1989), is relevant on this point, insofar as it diminishes the pressure on employers who do not engage in discriminatory practices to nonetheless adopt numerical quotas as a "safe harbor" against Title VII litigation in which they bore a heavy, uncertain, and often expensive burden of justification.

48. This conclusion must remain tentative. It is based on the fact that it was Justice O'Connor who wrote for a majority of six in Johnson v. Transportation Agency, 480 U.S. 616 (1987), reaffirming United Steelworkers v. Weber, 443 U.S. 193 (1979), of which the latter is the leading case on the legality of private, voluntary affirmative action under Title VII. I say the conclusion must be tentative because there are hints in both Johnson and Bakke that at least for public employers, the constitutional and statutory standards are the same. If those hints carry through and if the Court declines to impose a different test for public and for private employers, then Croson may spell a change in the jurisprudence of Title VII as well. As the text indicates, I would regret this. To my mind the cleanest way to maintain the distinction in this sphere between the public and the private-so generally important to a regime of liberty-is to have one standard for all employers under Title VII, but a different one (that of Croson) for suits claiming violations of the Constitution. 
